\title{
Аналіз рекомендацій з медичної реабілітації осіб з інвалідністю
}

\author{
Безсмертний Ю. О., Безсмертна Г. В. \\ Науково-дослідний інститут реабілітації осіб з інвалідністю Вінницького національного \\ медичного університету ім. М. І. Пирогова, м. Вінниця, Україна
}

Основними формами реабілітаційних заходів, що представлені в індивідуальній програмі реабілітації (ІПР) особи з інвалідністю, є: надання реабілітаційних послуг (3 медичної, професійно-трудової та соціальної реабілітації); забезпечення технічними та іншими засобами реабілітації, виробами медичного призначення; матеріальне забезпечення. Обсяг рекомендацій з усіх видів реабілітації, що призначаються щороку медико-соціальними експертними комісіями України, є масштабним. Так, у 2017 р. рекомендації з медичної реабілітації в ІПР були визначені 511855 особам 3 інвалідністю, в т.ч. 3 відновної терапії - 495779 особам, що склало 96,86\% від усіх рекомендацій 3 медичної реабілітації, з реконструктивної хірургії - 11455 особам (2,24\%), ортезування - 4621 особам (0,90\%), причому відносні показники практично не відрізнялись від минулорічних.

Рекомендації 3 медичної реабілітації здебільшого визначались особам з інвалідністю III групи (61,69\% від загальної кількості), потім - 3 інвалідністю II групи (30,63\%) і лише $7,68 \%$ - 3 інвалідністю I групи (більшість рекомендацій 3 медичної реабілітації надавалась особам з І-Б групи), хоча ця категорія осіб потребує більшої уваги лікувальнопрофілактичних закладів.

Така ж тенденція простежується майже в усіх окремих областях. Лише в Чернігівській та Запорізькій областях рекомендації з медичної реабілітації визначаються особам
3 інвалідністю I групи відповідно у 11,88 та $11,67 \%$ випадків; в той же час у Харківській області цей показник складає лише $4,51 \%$. Незначний відсоток рекомендацій 3 медичної реабілітації призначається особам II групи у Чернівецькій $(19,84)$ та Кіровоградській $(20,10)$ областях, натомість представникам III групи в цих же областях (а також у Тернопільській та Рівненській - більш ніж у $70 \%$ випадків. Лише в Одеській області та м. Києві заходи медичної реабілітації призначаються приблизно в рівній мірі особам з інвалідністю II та III груп, а в Черкаській області особам II групи медичну реабілітацію призначають частіше, ніж III групи (52,36 та 38,22\% відповідно).

Представленість відновної терапії серед усіх заходів медичної реабілітації коливається від 89,21\% у Донецькій області до $100,0 \%$ - у Житомирській. Натомість представленість реконструктивної хірургії набагато менша. Найчастіше вона визначається в ІПР у МСЕК Херсонської (6,35\%) та Донецької $(6,26 \%)$ областей, найменше у Житомирській (не призначається взагалі), Івано-Франківській $(0,02 \%), \quad$ Харківській $(0,13 \%)$, Запорізькій та Львівській областях (по $0,90 \%$ ).

Для осіб з інвалідністю I групи найбільший відсоток рекомендацій $з$ цього заходу визначений у м. Києві та Львівській області (18,46 та $14,93 \%$ - відповідно), II групи в Закарпатській $(54,72 \%)$ та Черкаській (48,62\%), III групи - в Полтавській $(81,64 \%)$, 
Харківській (77,14\%) та Вінницькій (76,32\%) областях. Найменшою є питома вага цих рекомендацій серед заходів медичної реабілітації для представників I групи у Тернопільській $(0,16 \%)$, Полтавській $(0,24 \%)$ та Житомирській областях (в останній рекомендації з цього реабілітаційного заходу для осіб I та інших груп взагалі не визначались); для представників II групи - у Полтавській $(18,12 \%)$ та Вінницькій $(20,65 \%)$ областях; III групи - м. Києві $(39,67 \%)$, Львівській $(36,81 \%)$ та Житомирській областях (в останній рекомендації 3 реконструктивної хірургії взагалі не визначались).

Ще рідше призначається особам 3 обмеженими можливостями ортезування, причому в Житомирській та Черкаській областях воно не призначається взагалі, в Івано-Франківській, Миколаївській та Чернігівській областях - лише в поодиноких випадках; натомість у Донецькій та Полтавській областях цей реабілітаційний захід визначається найчастіше $(4,54$ та $3,10 \%$ від усіх медичних реабілітаційних заходів - відповідно). Аналогічна ситуація з цим різновидом медичної реабілітації спостерігалась і в минулому році.

Залежно від важкості інвалідності по Україні найбільше рекомендацій з ортезування було визначено в ІПР особам з інвалідністю III групи (56,65 \% від загальної кількості), найменше - I групи (10,47 \%), причому переважна кількість їх надавалася представникам
I-Б групи; особам II групи було визначено $32,87 \%$ від усіх рекомендацій. Серед областей за показником рекомендацій 3 ортезування, визначених особам I групи, лідирувала Івано-Франківська область (40,0\%), II групи Закарпатська область (55,76\%), III групи Херсонська (80,00\%). Взагалі не призначався цей реабілітаційний захід для представників I групи в Житомирській, Миколаївській, Чернігівській та Черкаській областях.

Слід зазначити, що у 2017 р. порівняно 3 2016 р. дещо (на 0,6\%) зменшилась питома вага осіб з інвалідністю I групи, яким були призначені рекомендації з реконструктивної хірургії та ортезування, проте було більше звернуто уваги на призначення ортезування представникам I-A групи порівняно з минулим роком (цей показник збільшився для I-A групи на $1,63 \%)$.

Отже, серед визначених медико-соціальними експертними комісіями України у 2017 р. особам 3 інвалідністю понад 511 тис. рекомендацій 3 медичної реабілітації охоплення відновною терапією наближалося до $100 \%$, натомість представленість реконструктивної хірургії була набагато меншою $(2,24 \%)$, ще рідше призначалось ортезування $(0,90 \%)$. Рекомендації 3 медичної реабілітації здебільшого визначались особам з III групою інвалідності (61,69\%) i лише 7,68\% - 3 I групою, хоча ця категорія інвалідів потребує більшої уваги лікувально-профілактичних закладів. 